\title{
Business School Teachers' Experiences with a Student with Autism Spectrum Disorder
}

JAKA VADNJAL ${ }^{* 1}$ AND DARINKA RADOJA ${ }^{2}$

$\approx$ Autism has become an increasingly relevant topic in the research of neuroscience with the objective of enabling people with this condition to become equal opportunity members of the society; this includes an exploration of the benefits of the public education system. However, the science and knowledge in this field have thus far been limited, and the results of scientific findings have been very rare. The objective of the study was to explore primarily the first experiences of higher education teachers dealing with a student with an autism spectrum disorder. The aim was to learn lessons and contribute to some new understanding of special and adapted pedagogical approaches. The methodology of the study is qualitative, using (i) a case study as an objective of the researchers, and (ii) in-depth interviews with the twelve teachers about their experience with (for them) the new demanding assignment to teach a student with an autism spectrum disorder. The case study is about three years of undergraduate studies of a student with autism spectrum disorder who, in the end, obtained a bachelor's degree in the field of business. The findings reveal that teachers generally viewed the experience as very positive and found teaching to be a challenge. For success, cooperation with experts and parents is crucial, but the education institution (of which all are stakeholders) could and should have done more. However, taking into account that the challenge is new, this study may contribute to some further development.

Keywords: autism, business school, students, teachers, programme adaptation, parents

$1 \quad{ }^{\star}$ Corresponding Author. Slovenia; jaka.vadnjal@gmail.com.

2 Slovenia. 


\section{Izkušnje učiteljev poslovne šole s študentom z motnjo avtističnega spektra}

JAKa VADnjal in DARINKa Radoja

$\approx$ Avtizem postaja vse pomembnejša tema raziskovanja v nevroznanosti s ciljem omogočiti ljudem s to boleznijo, da postanejo enakopravni člani skupnosti z enakimi možnostmi uživati ugodnosti javnega izobraževalnega sistema. Znanstvene raziskave na tem področju so zelo omejene in redko uporabljene v praksi. Namen študije je bil raziskati večinoma prvo izkušnjo visokošolskih učiteljev v poučevanju študenta $\mathrm{z}$ motnjo avtističnega spektra. Cilj članka je spoznati nekatere ključne ugotovitve in prispevati k razumevanju namenskih pedagoških pristopov. Uporabljena je bila kvalitativna raziskovalna metoda, in sicer: i) študija primera študenta kot glavni objekt raziskovanja; ii) poglobljeni intervjuji z dvanajstimi visokošolskimi učitelji o njihovih izkušnjah $\mathrm{z}$ za njih novo in zahtevno nalogo poučevati avtističnega študenta. Študija primera govori o triletnemu študiju študenta $\mathrm{z}$ motnjo avtističnega spektra, ki je na koncu diplomiral s področja poslovnih ved. Ključne ugotovitve raziskave so, da so učitelji v splošnem zadovoljni z novo izkušnjo in da jo ocenjujejo kot velik izziv. Za končni uspeh je ključno sodelovanje $\mathrm{z}$ drugimi strokovnjaki in s starši, vendar bi uradni izobraževalni sistem na tem področju lahko in moral storil več. Po drugi strani pa je treba priznati, da gre za nov strokovni in znanstveni izziv; upamo, da bo ta članek prispeval k njegovemu nadaljnjemu razvoju.

Ključne besede: avtizem, poslovna šola, študentje, učitelji, prilagoditev programa, starši 


\section{Introduction}

Autism encompasses a spectrum of disorders, ranging from classic autism, high-functioning autism, Asperger's syndrome, and atypical autism, to other unspecific pervasive development disorders. In all cases, problems occur in three fields: social interaction, communication, and stereotypic behaviour. The cognitive status of the person with autism spectrum disorder is dependent upon the severity of the disorder. In addition, people with autism spectrum disorder tend to have more heightened senses, thus receiving many more information/stimuli from the environment than an average person does. Sensory hypersensitivity is commonly accompanied by a different sensory integration, thus making the reception of a large amount of information even more difficult, and thus the environment may become unbearable for the person with an autism spectrum disorder. To defend themselves from such disturbing influences of the environment, people with autism spectrum disorder create a 'defence mechanism' (stereotypic games) in order to help themselves 'erase' or alleviate the world and build their own, which is more comprehensive and acceptable: a world in which they have complete control over the stimuli, and which is predictable (Autism Treatment Centre Ljubljana).

Asperger's syndrome is classified as a high-functioning form of autism, lacking development disorders, yet characterised by difficulties in social interaction, communication, and a restricted range of interests that is seen in play, imagination, and behaviour. People with Asperger's syndrome are described as being more socially motivated but very sensitive. This syndrome has been commonly used as a conceptual bridge between autism and the general population (Jurišič, 2012; Klin, McPartland, \& Vokmar, 2005). Asperger commented about children with autism spectrum disorder never being 'on the same wavelength' as their neurotypical peers in any group activities (Frith, 1989).

Autism is categorised under the Pervasive Developmental Disorders (PDD) category as described by the American Psychiatric Association. It is marked by deficits in reciprocal social interaction, communication (verbal and nonverbal), and a restricted repertoire of activity and interest (American Psychiatric Association, 2000). Children with autism spectrum disorder have a relatively limited prognosis and usually require special care (Attwood, 1998). The nature of autism usually requires a wide range of services (e.g., health and medical, rehabilitative, and educational). These services might require parents to interact with multiple providers, try different types of services or treatments, and dedicate their time, money, and energy (Goin-Kochel, Mackintosh, \& Myers, 2009). Providing formal support for them and their parents is essential to 
improving children's abilities and enhancing the capabilities of parents. Once it was believed that children with autism were not able to learn anything, so they did not deserve any special attention. In the past, many adults with autism did not learn to read or count above the level of the early years of primary school, although there are some rare individuals with autism spectrum disorder who achieved a high level of education (Volkmar, Reichow, \& McPartland, 2014).

The motivation for this study was the very first experience of one of the two researchers with autism spectrum disorder or, more precisely, with the organisation of pedagogical work at a small college for business studies at which a student with autism spectrum disorder enrolled for the first time. For the majority of teachers and study support staff, this was a new direction, and the challenge for the college was to react accordingly to this new professional issue. The study was conducted when the student had already passed all the exams and other formal learning obligations and was working on the preparation of his graduate thesis.

The present paper, which has the objective of both giving some theoretical background and sharing some findings of teachers has the following structure. After the introduction and theoretical background with the research questions defined, the methodology, which is qualitative, is presented. The methodology has two components: first, the case study on the student and his launch of the study; second, the research conducted among teachers. Next, some results and findings are given, and some discussion and implications are provided in the conclusion.

\section{Theoretical background and research questions}

Because autism encompasses such a wide spectrum, the symptoms tend to appear in different ways and at different ages. The symptoms most commonly show up in the second or third year, when a neurotypical child becomes progressively sociable, and starts to talk and play with their parents and peers. In contrast, children with autism spectrum disorder tend to withdraw into their own world and do not seek social contact. The parents are usually the first to notice their distinctive reactions. Autism may lead to a decline or loss of previously acquired skills, such as speaking, walking, etc. The symptoms of autism are sometimes noticed as late as in primary school (Društvo za avtizem DAN).

The symptoms of disabilities of the autism spectrum are highly heterogeneous due to the complexity of interactions among genes, brain, and behaviour throughout development (Pelphrey, Shultz, Hudac, \& Vander Wyk, 2011). Differences in cognitive abilities contribute to the heterogeneity of autism while 
serving as a kind of predictive factor of later development result of each individual (Kuhl, Cofey-Corrina, Padden, Munson, Estes, \& Dawson, 2013). A study that examined the relationship between the age of language acquisition and later functioning in children with autism spectrum disorder showed that meaningful language use by the age of five seems to be a powerful indicator of a positive outcome (Mayo, Chlebowski, Fein, \& Eigsti, 2013).

\section{Cognitive Theories on Autism Spectrum Disorder}

The cognitive and social symptoms of autism may overlap and are highly interconnected. The social deficits of individuals with autism spectrum disorder may be directly related to the degree of their general cognitive functions (Richardson, 2008). The four cognitive theories dealing with the alternative cognition of autism are as follows.

The theory of 'mind-blindness' (Baron-Cohen, 1997) states that individuals with autism spectrum disorder cannot tell what others are thinking, which is the critical factor for appropriate social reasoning and communication. However, they may learn to interpret the mental states, understanding of emotions, facial expressions, and empathy very well (Howlin, Baron-Cohen, \& Hadwin, 1999).

The 'executive dysfunction' theory (Hill, 2004) states that individuals with autism spectrum disorder have problems with planning, organisation, controlling attention, inhibition of impulses, updating of information, and working memory. This theory attempts to explain the repetitive stereotypic behaviour and socio-communicative difficulties in autism (White, 2012).

The 'weak central coherence' theory (Happe \& Frith, 2006) is defined by problems with the perception of the whole or inability to see the big picture, the lack of an ability to process information globally. Some resemble the clinical picture of autism as submitted by Kanner and Asperger: limited interests, resistance to change, individual above-average abilities, excellent orientation memory, and obsession with details (Lawson, 2011).

'Enhanced Perceptual Functioning' (Mottron, Dawson, Soulieres, Hubert, \& Burack, 2006) is the latest cognitive theory, and thus the least studied. The theory proposes that the excessive brain function, i.e., processing of different sensory and motor information act in a manner as to enable a different perception. The individuals with autism spectrum disorder are thus believed to learn in a different manner: more spontaneously and implicitly, which is not necessarily bad (e.g., a combination of narrowly focused attention and reinforced senses can yield amazing results). The theory serves to explain why some 
individuals with autism spectrum disorder are remarkably successful at certain tasks (Lawson, 2011).

\section{Cognitive Functions and Autism}

\section{Information Processing and Encoding}

Autism represents an obstruction that exists between the senses and the mind (Waleski, 1997 in Bryson, 2005). Thus, the incoming information may be incomplete or distorted. Different types of sensory stimuli may be unusually intense (Grandin, 1995) as to cause an excessive arousal state, in which the senses block the mind; the reception of information is thus incomplete and distorted. Excessively focused attention in autism appears to be associated with the analytical method of processing information, which enables higher performance in the tasks of reconstruction. Such an approach to the world seems to be associated with a higher propensity to sequential processing of information rather than parallel, due to the excessive orientation of attention to detail, which inhibits simultaneous processing of multiple sources of information. As a result, the information is stored in separate 'folders', rather than by their conceptual or semantic relations, which results in a high level of accuracy, but comes at the expense of lacking categorisation and generalisation (Bryson, 2005).

\section{Emotions and Mindset}

Autism is characterised by a lack of emotional expression; however, this is not equal to being indifferent to emotions. Kanner (1943) believes that people with autism experience a range of emotions, but they do not always know how to express them. In autism, the emotions are expressed atypically (e.g., flapping hands or movement). Extreme emotions may cause catatonic-like freezing in individuals with autism spectrum disorder (Wing, 2000 in Bryson, 2005). Controlling emotions by thinking is problematic due to weaker self-awareness. An individual with autism spectrum disorder has problems interrupting an important event or thought, which may become a source of obsessive attention, controlled by anxiety. Withdrawal from such emotional events is very difficult, as they cannot think of anything else (Rothbart et al., 1992 in Bryson, 2005).

\section{Language and Communication}

Individuals with autism spectrum disorder encounter delays and deficits in language acquisition, ranging from complete absence of functional communication to nearly adequate speech. About half of individuals with autism spectrum disorder never adopt functional language (Bailey et al., 1996 in 
Tager-Flusberg, 2005). Parents of children with autism often report that the first sign of trouble became apparent by the absence or loss of speech at around two years of age (Kurita 1985; Lord and Paul, 1997 in Tager-Flusberg, 2005). Some children with a milder form of autism regain the ability to communicate and acquire a certain degree of functional language around the age of five, which proved to be the most predictive factor for a favourable developmental outcome of the autism spectrum (Rutter, 1970; Ventner et al., 1992 in Tager-Flusberg, 2005). Kanner (1946) first noticed that children with autism often only repeat words, phrases or sentences, as a kind of echo. This feature of autism is called echolalia and is typical in children who have very little productive speech. Currently, echolalic speech is considered to have functional value, as it enables them to preserve some sort of role in the conversation, even if they do not understand or have not mastered the skills necessary for an appropriate response.

\section{Executive Functions and Memory}

The executive functions disorders are associated with all three categories of behavioural symptoms of the autism spectrum, with impairments of reciprocal social interactions, communication, and stereotypic behaviour (Kenworthy, Black, Harrison, Rosa, \& Wallace, 2009). Some of the symptoms of autism may be explained by memory deficits, for example, inappropriate comments of a person with autism spectrum disorder might be attributed to the fact that he or she cannot remember the topic of the conversation. Similarly, the repetitive movements can be explained by the inability to retrieve the memory of the previous activity. A quite probable explanation may lie in the fact that what looks like the deterioration of memory functions in persons with autism spectrum disorder could be a consequence of a different type of information processing and organisation, thus leading to poor performance on memory tests (Killiany, Moore, Rehbein, \& Moss, 2005).

\section{Peculiarities in learning with autism spectrum disorder}

Bogdashina (2005) suggests that the 'triad of impairments' (social interaction, communication, and imagination), which is the main feature of autism, would be better described as qualitatively different modes of interaction, communication and information processing, which do not overlap with conventional methods. People with autism may also have other problems, such as sleeping problems, eating problems, fears and phobias, problems with motor skills, and others (Hannah, 2009). All this has a strong influence on the course of their learning. There is a strong correlation between autism and various 
learning difficulties. Two-thirds of people with autism have profound learning difficulties. Learning difficulties are a risk factor for the development of behavioural disorders (Dobnik-Renko, 2009). Autism has a high comorbidity with attention deficit and hyperactivity disorder (ADHD), which has a negative impact on individuals' intellectual development (McTighe, Neal, Lin Hughes, \& Smith, 2013). The lack of attention often leads to difficulties in understanding longer texts and instructions.

A typical problem in autism is learning abstract concepts. The ability to learn abstract rules from specific experience is crucial for a wide range of areas, including categorisation, language and social behaviour. Individuals with autism show difficulties in learning, application and flexibility of abstract rules. This affects their ability to respond appropriately in social situations (Jones, Webb, Estes, \& Dawson, 2013). Many things that people usually learn spontaneously and intuitively as social skills, people on the autism spectrum have to learn as a special subject in school. Grandin (2013) says that over the years she learned some basic emotions, often in the form of mathematical equations. She describes her social learning as 'a strictly logical process'. Some never understand such acquired social skills in their true sense, but they know how to use them effectively enough. Individuals with high-functioning autism and Asperger syndrome often develop compensatory strategies to conceal their inability to understand social situations.

\section{Autism in the formal education system}

Today, children with autism can be and are mostly included in society with adequate professional help and support. They often attend mainstream schooling with individually adjusted programmes according to their needs so that they can participate in the educational process (Dobnik Renko, 2009). Working with children with autism represents a challenge for those who are engaged with them (e.g., teachers, paraprofessionals, primary health providers and parents). The challenge emerges from

[...] the heterogeneity of students' characteristics and needs, the idiosyncratic and occasionally severe nature of the students' behavioural challenges, the dramatic increase in the prevalence of autism spectrum disorders, the strongly held and diverse opinions regarding appropriate intervention and the litigious atmosphere engendered by these opinions. (Dunlap, Iovannone, \& Kincaid, 2008, p. 111) 
In Slovenia, children with autism spectrum disorder are included in the mainstream schooling system as children with special needs according to the Law on the Placement of Children with Special Needs (Ministry of Education and Sport, 2011). They are addressed as children with autism spectrum disorders. They are placed in programmes with adapted implementation and additional professional assistance, adjusted programmes with lower educational standards or special educational programmes. It is possible to switch between programmes. An individualised educational programme is prepared, which details the objectives and methods of work for each child. To enable the successful inclusion of children with autism spectrum disorders, more attention should be paid to the field of socialisation, communication and functional objectives in the cognitive domain (Working Group of the Ministry of Health, 2009). It appears that inclusion does not work for children with autism spectrum disorder as it should (Harvey, 2011). In education, there is currently a trend to place all students with disabilities in mainstream education settings or so-called mainstreaming. As the number of students with autism spectrum disorders in mainstream classes is increasing, so are the challenges for educators. Due to the very nature of autism spectrum disorders, mainstreaming may result in 'exclusion' of the student if his social needs are not being met by the environment (Little, 2017).

In the past, the term 'inclusion' was used interchangeably with 'integration' to refer to the location in which a child was educated (Warnock, 2005). Today, these two concepts are distinguished based on the course of involving children with special needs in mainstream education. 'Integration' implies that a child with special needs will adapt to the environment of mainstream education with no additional support. 'Inclusion', in contrast, is not simply about where an individual is educated: it is about the quality of the support he receives. It involves the restructuring of the curriculum and classroom organisation (Barnard, Prior, \& Potter, 2000).

At the beginning of the educational path, there is more focus on early intervention and special education with a team approach to educating students with autism spectrum disorder and a role for parents as equal partners in the planning for an individual child. This model promotes education in the least restrictive environment. The objective is to place students in as natural a learning environment as possible, within their home community, to the greatest extent possible. The participation of students with autism spectrum disorder in the general education environment is often called 'mainstreaming' or 'integration'. A variety of supports is provided to create a successful environment and experience for everyone involved. Careful planning and training are essential 
to provide the right modifications and accommodations. Supports might include a specially 'trained' classroom or one-on-one paraprofessional, altering testing environments or expectations, adapting curriculum, visual supports or adaptive equipment, etc. Educating students with autism spectrum disorder is usually an intensive undertaking, involving a team of professionals and many hours each week of different instruction and therapies to address a student's behavioural, developmental, social, and academic needs (Autism speaks, 2012).

The transition into adulthood is very hard for somebody on the autism spectrum, mostly because of the loss of structure that school provided for six hours a day as well as the loss of contact with people he saw every day for years. For individuals on the spectrum, every transition is difficult, whether transitioning from one place to another, one activity to the next, or from one major life event to another, such as from secondary school to college (Sicile-Kira \& Sicile-Kira, 2012). While in the past individuals with autism spectrum disorder were considered to be unlikely to have the academic potential to pursue higher education, the landscape has dramatically altered as interventions have improved and as our understanding of the spectrum has been modified to include a broader range of behaviours and disabilities. Today, the majority of young adults identified with autism spectrum disorder intend to go to college with a goal of achieving higher-level employment and independent living (Wagner, Newman, Cameto, Levine, \& Marder, 2007). Researchers have suggested that high functioning students with autism spectrum disorder will achieve optimal results in an integrated, support-based system, as opposed to separate, self-contained programmes (VanBergeijk, Klin, \& Volkmar, 2008). These programmes use peer mentors or facilitators, often specifically trained fellow students majoring in social science graduate or undergraduate programmes, who can support students in an unobtrusive manner. Fellow students act as 'social navigators'. Their role is to alter the student's outsider status by introducing them to their friends.

Many individuals with autism spectrum disorder have significant academic strengths, often in the technological, mathematical, and mechanical fields (Wagner, Newman, Cameto, Levine, \& Marder, 2007). Although there is a growing demand for students to enter science and technological fields, employment prospects for people with autism spectrum disorder remain poor, often because of general social deficits (Turnbull, Turnbull, Wehmeyer, \& Park, 2003). A study on the participation among college students with autism spectrum disorder suggest that they had the highest science, technology, engineering, and mathematics participation rates although their college enrolment rate was the third lowest among eleven disability categories and students 
in the general population (Wei, Yu, Shattuck, McCracken, \& Blackorby, 2013). The cost of losing the contribution of this unique population will be borne by both the individuals affected and by the rest of society. Students with autism spectrum disorder may be assisted to productive, creative adult lives or face more limited futures surviving on benefit payments. Existing programmes have demonstrated what is needed so that these students need not fail, but flourish. These programmes should be publicly funded and developed and should be considered not as a cost but as an investment for a better future for everybody.

The two research questions can, therefore, be derived from the literature review and some of the experience and subjective views of the researchers:

1. What was the level of awareness on autism among the college teachers and possible readiness to learn more in order to adapt their pedagogical activities with the student?

2. Is there any room for improved action on the side of the institution for more efficient and effective inclusion of the student with autism spectrum disorder into the teaching/learning process?

\section{Method}

The methodology of the study can be explained in two parts. The first part (called 'the case study' in section 3.1 of this paper) is the story of a student with an autism spectrum disorder diagnosis, which caused some serious challenges to the management and organisation of a business college. He enrolled with the assistance of his parents and solely on the basis of the formal administrative requirements (finished secondary school). It seems that everybody involved in the process of enrolment (i.e., parents, medical doctor(s) and school) were fully aware of all the potential risks and challenges that would arise once the student became a full part of the study process. Practically no preparations were taken, neither with the teachers, nor the administrative staff. It seemed that the biggest burden of dealing with specific learning issues and requirements of the particular student was placed on the shoulders of the teachers.

Thus, in the second part of the study (titled 'the interviews' in section 3.2 of this paper), teachers were asked about their (in most cases) first professional experience with a student with autism spectrum disorder. For the first part of this paper, the case study method was used, involving mostly a method of description combined with some secondary data (Weiss, 2010), because the study on the same student's evolvement through the first and secondary levels of the school system has previously been published. Therefore, the presented story is 
based on the synthesis of the description and secondary source utilisation. In the second part, teachers were interviewed regarding their experience with the student. The semi-structured interview was the method utilised on the sample of teachers, who took active pedagogical roles in the student's study process.

\section{The case study}

The story of the case study was rather simple. A male student ('Peter', a pseudonym) with the diagnosis of Asperger's syndrome enrolled at the age of 19 in the undergraduate business studies programme run by a relatively new independent business college. Known from the personal relationship of the researchers with Peter's parents, his particular case study was described before in some earlier work aiming to explore the role of the schooling system in the social development of children with autism spectrum disorder (Weiss, 2010). There are certain general legal regulations on the level of the country concerning the treatment of children and students with special needs in the education system.

These regulations, which are frequently more like directions than specific requirements, do pass a substantial level of proactive responsibility to the institutions to organise their teaching and learning processes so that children and students with disabilities are not placed into an (even) more unequal position compared to their classmates. Unfortunately, although there are quite high requirements from the government, there is little or no assistance offered. 'Autism' is a new term in the field of the discussion and planning pedagogical treatments influenced by the 'special-need' requirement in comparison to some other conditions for which there has traditionally been much more knowledge and experience (e.g., physical disabilities, deafness). Therefore, the ways of tackling these new issues faced by the schools are to a great extent left to the management of the education institutions. Very often there are severe constraints in the field of knowledge, experience, expertise, staff and, in higher education, additional limitations of academic freedom, which give teachers the right and responsibility of practically everything that is happening in the classrooms but, also regarding the workload and understanding of expected achieved competencies and learning goals.

In the letter of recommendation issued by the national education authority, which is based on Peter's medical documentation, it is stated, that 'inclusion in the education is very important for his personality development and mental health, however there is a need for methodological and time adaptations. The specific recommendations in the letter include: (i) avoiding stressful 
situations like suddenly asking the student questions; (ii) assistance in providing study materials; (iii) close cooperation with his parents as mentors; (iv) short and clear instructions with repetition of those if needed; (v) more time available for written examinations and oral examinations when this is possible; and (vi) avoiding exposure to classmates when this is possible and, some others, which are in compliance with listed above. Peter started attending classes, but only the teachers were notified that they had 'a different guy' in the classroom.

Peter's classmates were not prepared for this (for them) new situation, and very soon a couple of conflict situations evolved. Some students started to make jokes triggered by some of Peter's unusual behaviour mostly expressed with extreme politeness to other people, verbalised in highly artistic phrases that are not common (even archaic) in everyday conversations; moreover, they sometimes were accompanied some explicit facial gesticulations. Only a couple of weeks after the start of the study year, a workshop was organised by the college management and was run by Peter's specialist doctor. Teachers and classmates were invited to have Peter's special condition explained by an expert and discussed. Most probably, for the majority of the workshop participants, this was their first formalised contact with autism.

From what is described, it is very obvious that the requirements of Peter's enrolment were heavily underestimated by all stakeholders: the parents, the doctor, and the school management. The reasons for this may be multilayered. On the one hand, one cannot blame the school for lack of experience in the field. Similarly, the doctor should have given some professional input before the process was started, but it seems that this was limited to administrative and legislative details. On the other hand, the parents are not to be expected to reduce their wish to do the best for their child. In the end, it all seems the situation was to a great extent delegated to teachers who, one by one, tackled the situation according to their best professional judgement.

\section{The interviews}

Sixteen teachers were invited to give an interview regarding the proposed issue on working with the student. Eleven teachers who taught the student agreed to participate in the study and to provide feedback through interviews. Additionally, a teacher who was not actively teaching but was intensively involved with the approach to this new challenge for the academic staff was willing to provide insights from his side. There were five other teachers involved in teaching the student. One of them rejected an interview because she thought that the topic was too personal to be researched in this way and argued this 
point with the fact that they had a similar issue in her extended family. One teacher retired after teaching the student and replied: 'I have nothing to do with this issue anymore.' Two teachers repeatedly ignored emails with the request for interviews. Derived from the personal acquaintance with both teachers there is a strong belief that because of certain personal reasons (in one case, a conflict between the teacher and Peter's father in the role of his mentor) they did not feel comfortable participating in the study.

Table 1

Some demographics on study participants

\begin{tabular}{llcccccc}
\hline Teacher & Gender & Age & $\begin{array}{c}\text { Own } \\
\text { Children }\end{array}$ & $\begin{array}{c}\text { Discipline } \\
\text { taught: Soft/ } \\
\text { Hard }\end{array}$ & $\begin{array}{c}\text { Number } \\
\text { of hours } \\
\text { taught }\end{array}$ & $\begin{array}{c}\text { Additional } \\
\text { hours } \\
\text { spent }\end{array}$ & $\begin{array}{l}\text { Educational } \\
\text { background } \\
\text { Social/Technical }\end{array}$ \\
\hline T1 & Male & 57 & 3 & Soft & 150 & 30 & Social \\
T2 & Male & 54 & 1 & Soft & 96 & 10 & Social \\
T3 & Male & 52 & 0 & Soft & 60 & 5 & Social \\
T4 & Female & 32 & 0 & Hard & 60 & & Technical \\
T5 & Male & 56 & 2 & Hard & 35 & 3 & Technical \\
T6 & Female & 33 & 0 & Soft & 40 & 3 & Social \\
T7 & Female & 55 & 2 & Hard & 150 & & Social \\
T8 & Male & 54 & 2 & Soft & 30 & & Social \\
T9 & Male & 57 & 3 & Soft & 60 & & Social \\
T10 & Female & 43 & 1 & Hard & 150 & 15 & Social \\
T11 & Male & 39 & 0 & Hard & 60 & 20 & Social \\
T12 & Male & 49 & 3 & Hard & 0 & 30 & Social \\
\hline
\end{tabular}

Some demographics on the study participants are presented in Table 1. Four women and eight men gave interviews. This is somewhat comparable to the gender ratio of people teaching at the college. Regarding age, two women were in their thirties, one woman in her forties, and remainder in their fifties. The two youngest women did not yet have children and, additionally, two men were without children. The taught disciplines were robustly differentiated as (i) hard ones, which are more based on numbers (i.e., economics, statistics, accounting, finance) and (ii) soft ones, which are more essayistic or narrative (i.e., management, entrepreneurship, marketing, human resource management). Six teachers came from the hard side of business studies, and the remaining six from the soft side.

Regarding educational background, two teachers were from a technical background while the rest mostly had different level degrees in business-related 
fields. The lowest level of formal education was a master's degree while seven study participants held doctoral degrees. All the study participants have the length of their teaching experience in correlation with their age, and nobody had less than five years of teaching experience. The number of hours they taught Peter was very different, ranging from 30 (one teacher did not teach at all) up to 150 hours. The reason for this is that different courses consisted of different numbers of contact hours in the classroom and some teachers were teaching more than one course. In total, Peter had to pass 22 exams, and he wrote and successfully defended his thesis.

The majority of the interviews were conducted in written form (questions sent through email) with some later clarifications by phone or at the meeting when this was necessary in a couple of cases in which, surprisingly, study participants were not comfortable providing written answers. The period of conducting the interviews was late 2014, but no findings were revealed before Peter successfully graduated in the same period. Total confidentiality was promised to study participants with the objective of personal data and opinion protection. However, from the demographics displayed in Table 1, there is a slight chance that someone who knew the situation and people involved in the research well could make a good guess who the study participants were. However, no personal opinions are revealed in the study. Additionally, there is a certain time difference between the study and the date of possible publication. Therefore, it is believed that anonymity is entirely assured.

\section{Results}

There were in total twenty questions asked to participants of the study. It turned out that two questions were asked too directly to evaluate some personal abilities of the student, which probably led to a certain reluctance on the side of teachers to frankly and openly respond to these questions. For this reason, the analyses of these two questions were omitted from the study, leaving eighteen questions for the further discussions. The summary and some quantifications of responses are displayed in Table 2.

Nine teachers were informed about Peter's special learning needs from the college's management before the lectures started. This was more a brief note rather than in the form of clear instructions and directions for the upcoming work and interactions with the student. Furthermore, some formal notice including a copy of Peter's medical report was sent to all the teachers just before they started their classes. The first workshop with the expert (doctor) was only organised after a couple of weeks of the ongoing lectures and after the evolution 
of some communication problems with Peter and his parents in the role of his mentors had already started. Also, some conflict situations arouse in the relation between Peter and some other fellow students who found Peter's unusual behaviour childish and sometimes even mocking to other people. Other students began to mock him back. In the opinion of the majority of the teachers, the college should have done much more to prepare teachers for this issue, for them mostly new professional challenge. They were missing more detailed and specific directions, and some of them even expressed doubt how appropriate this level of formal studies was for somebody with a medical condition like Peter's. Only three teachers felt that the college had performed adequately.

In the case of Peter, the majority of teachers encountered autism for the first time in their pedagogical careers. One person had never heard about this mental health issue before. Half of the teachers did some research on their own, using the internet, books, discussing experiences with colleagues and even by getting some opinions and advice from external experts. The majority of teachers never discussed Peter's issues with his classmates (with one exception) because they thought there was no need for this. The majority of teachers thought that the classmates accepted Peter very well after some initial hesitation and prejudices. The meeting with the expert was found to be very useful. Some students even tried to assist Peter while others, according to some observation from teachers, were avoiding interfering with him.

There were only three teachers who claimed that they felt no need to make any particular adaptations to their courses. In the majority of other courses, there were some modifications introduced for Peter: oral instead of written examinations, different design and form of the same exam questions (larger font, every question on separate page and no tricky word games), additional explanations and consultations regarding the content, more repeating and more time for examination. The majority of problems occurred in communication, the ability of explanation, linking different pieces of content and cooperation with parents. Other students generally did not mind the slightly different approach for Peter. The majority of teachers cooperated with Peter more intensively in comparison to other students. The majority of teachers evaluated Peter's progress to be comparable to that of other students. 
Table 2

Quantified responses to questions

\begin{tabular}{|c|c|}
\hline Question & Answers summary \\
\hline $\begin{array}{l}\text { Where and how were you acquainted with } \\
\text { Peter's special needs? }\end{array}$ & $\begin{array}{l}\text { Ten out of twelve received information from the } \\
\text { institution. }\end{array}$ \\
\hline $\begin{array}{l}\text { Have you heard about this handicap before? } \\
\text { Where and how did you get additional } \\
\text { information? }\end{array}$ & $\begin{array}{l}\text { Eight teachers heard and two were a little familiar } \\
\text { with the issue. Half of them searched for some } \\
\text { additional knowledge. }\end{array}$ \\
\hline $\begin{array}{l}\text { Did you discuss Peter's situation with other } \\
\text { students? }\end{array}$ & Generally, without exception. \\
\hline $\begin{array}{l}\text { Were there any special adaptations of your } \\
\text { course needed? How were those adaptations } \\
\text { understood by other students? }\end{array}$ & $\begin{array}{l}\text { Three teachers did not need to make any changes. } \\
\text { Other made adaptations according to recommen- } \\
\text { dations. Other students did not mind those course } \\
\text { adaptations. }\end{array}$ \\
\hline $\begin{array}{l}\text { How did, in your opinion, other students } \\
\text { accept Peter? }\end{array}$ & $\begin{array}{l}\text { Generally, very well with some drawbacks and } \\
\text { some avoidance of any contact. }\end{array}$ \\
\hline $\begin{array}{l}\text { Did Peter rely for help mostly on classmates, } \\
\text { teachers, or somebody else? }\end{array}$ & $\begin{array}{l}\text { In most cases, teachers felt that Peter mostly } \\
\text { relied on his parents for the help. }\end{array}$ \\
\hline $\begin{array}{l}\text { What kind of behaviour particularities did you } \\
\text { notice and how did you encounter those? }\end{array}$ & $\begin{array}{l}\text { Majority of teachers reported typical autism } \\
\text { behaviour characteristics. }\end{array}$ \\
\hline $\begin{array}{l}\text { Who did you address when you encountered } \\
\text { problems in communications with Peter? }\end{array}$ & $\begin{array}{l}\text { Majority of teachers who followed the expert's } \\
\text { instructions had no problem. }\end{array}$ \\
\hline $\begin{array}{l}\text { To what extent did you cooperate with Peter's } \\
\text { parents. }\end{array}$ & $\begin{array}{l}\text { Majority of teachers cooperated with Peter's } \\
\text { father. }\end{array}$ \\
\hline $\begin{array}{l}\text { To what extent did you individually cooperate } \\
\text { with Peter? }\end{array}$ & $\begin{array}{l}\text { Majority of teachers cooperated with Peter much } \\
\text { more than they cooperated with other students. }\end{array}$ \\
\hline How would you evaluate Peter's progress? & $\begin{array}{l}\text { Majority of teachers thought that Peter's progress } \\
\text { was comparable to other students. }\end{array}$ \\
\hline $\begin{array}{l}\text { Do you think you are adequately profession- } \\
\text { ally trained for work with students with this } \\
\text { type of special needs? }\end{array}$ & $\begin{array}{l}\text { Majority of teachers responded negatively to this } \\
\text { question. }\end{array}$ \\
\hline $\begin{array}{l}\text { In what area did you experience most prob- } \\
\text { lems in your work with Peter? }\end{array}$ & $\begin{array}{l}\text { Communication, explanation, linking differ- } \\
\text { ent pieces of content and communication with } \\
\text { parents. }\end{array}$ \\
\hline $\begin{array}{l}\text { How would you describe your experience in } \\
\text { teaching Peter? Did you learn anything? }\end{array}$ & $\begin{array}{l}\text { Half of teachers evaluated the experience as a } \\
\text { positive one and learned something. Others are } \\
\text { more indifferent. }\end{array}$ \\
\hline $\begin{array}{l}\text { To what extent will experience with Peter be } \\
\text { useful for your future work? }\end{array}$ & $\begin{array}{l}\text { Majority of teachers felt that this teaching experi- } \\
\text { ence would be useful. }\end{array}$ \\
\hline
\end{tabular}

Generally, the teachers did not report any particular problems encountered in doing their jobs with Peter. The assistance of the doctor was very useful, and so was the communication and cooperation with the parents. Some teachers mentioned some useful discussions with the student's office, dean, other colleagues, and the parents. For some teachers, the cooperation with parents was somewhat ambiguous. This communication was most intense before 
examinations, and some teachers reported feeling some unpleasant pressures from the side of parents, and there were even a couple of minor conflicts reported that were later resolved with some mediation from the side of the college's dean.

Although teachers generally agreed that there were no major problems with Peter, they mostly felt that they were not adequately trained to work with students with an autism spectrum disorder. For the majority of them, this was their first experience in which they had to include the reality of the disorder in their curricula. More information and clearer instructions would have been very useful. There were a couple of individuals who felt more confident than their colleagues regarding their competences to work with Peter. These were mostly teachers with some previous experience in working with people with special needs. In one case, more openness for the issue was, as expected, demonstrated by a teacher with an educational background in psychology. Seven teachers expressed that this particular experience would enrich and enhance their views of their pedagogical work in the future while the other seven skipped answering this question.

The quite detailed data on study participants were given in an attempt to indicate some pattern of opinions with the connection to certain demographic characteristics. After several trials using qualitative cluster methods, no patterns (or clusters) were identified based on age, having children, the discipline taught, or the number of taught and spent hours. The two possible patterns are that (1) female teachers tend to be more empathetic towards the student and that, (2) teachers with social science educational backgrounds had more understanding of the student's health condition.

To address directly the second research question, teachers' answers reveal several opportunities to improve further activities on the level of the institution for further improvement of the teaching/learning process. It is believed that these suggestions for improvement may be generalised to other higher education institutions with possible similar challenges in the future. First, teachers should be informed well in advance about the presence of students with special needs in the study process. Classroom activities may have to be adapted accordingly. The learning progress of a particular student may have to be different from the mainstream for other students, as well as the examination process. Second, a training meeting with direct suggestions on the possible special methods should be organised for all teaching staff with the goal of preparing the participants for possible unfamiliar situations. Third, different forms of consultation should be provided to teachers during the courses to assist them in making often difficult decisions about study process adaptations. Fourth and finally, one of the 
members of the teaching staff should be appointed to direct and facilitate the communication among all the stakeholders on this very specific topic.

\section{Conclusions and implications}

The field of autism remains a somewhat grey area. Most probably, the reason lies in the fact that until recently autism was a very rare disorder, and not many researchers showed interest in it. However, the sudden and unexplainable dramatic increase in the occurrence of autism in recent years has stirred interest in the media and professional circles. The short history of autism has seen a significant turnaround: from interpreting this disorder with psychogenic theories, to claiming that autism is caused by an error in the operation of certain biological processes. The adoption of empirical research methodology in order to explain the problems in the field of mental health has allowed for such changes in theories (Schopler, 1994). However, the neurobiological bases of changes in cognition in relation to autism are still not well understood. The ultimate objective is a complete characterisation of the origin and extent of changes in all areas of behaviour, including the processing of language, social skills, and all aspects of cognitive functions (Killiany, Moore, Rehbein, \& Moss, 2005).

There has also been significant progress regarding the inclusion of people with autism spectrum disorder into the formal education system, taking into account the necessary adaptations in teaching methods, pedagogical aids, and examination. Although there has been some evidence on the inclusion of children with autism spectrum disorder into primary schools, less has been said about their involvement in secondary programmes and very little, apart from some anecdotal evidence, about people with autism spectrum disorder studying at the higher education level.

Therefore, this study aims to be among the first contributions in the unexplored field of people with autism spectrum disorder studying on a higher educational level, at universities or colleges. Due to the academic freedom and independence paradigm, the work on this educational level is almost entirely left in the hands of teachers. Thus, the approaches in the cases of special needs students are essentially left to their own judgment, which cannot be based on anything else but their very limited experience in working with, in our case, students with autism spectrum disorders. No practical experience of any formal training on working with students with autism spectrum disorder has been found in the scientific literature thus far.

The main finding of this study can be summarised as follows. There is absolutely no need or excuse for any fear about not being able to deal with very 
often not understandable issues that accompany the diagnosis of autism. There is an urge for very strong connections between the different internal stakeholders (students, teachers, parents, university management) and the external expertise providers. The body of knowledge on pedagogical best practices needs to be developed and constantly upgraded in order to develop a flexible, but still sustainable pedagogical model. This would leave enough space for both prerequisites that need to be taken into account before somebody is awarded a degree and specific academic feature that remain essential to higher education. Thus, it should be strongly encouraged that every new case and experience is carefully studied and examined. The objective of doing so is the creation of best practices and constant improvements for everybody involved in professional work with people with autism spectrum disorders. It is about helping the people with autism spectrum disorders to reveal all their hidden potentials and to assist their parents and families, who very often devote their entire lives to being able to understand this life, still full of secrets.

\section{References}

American Psychiatric Association. (2000). Diagnostic and statistical manual of mental disorders: Text revision (4th ed.). Washington, DC: American Psychiatric Publishing.

Attwood, T. (1998). Asperger's syndrome: A guide for parents and professionals. London, UK: Jessica Kingsley Publishers.

Autism Speaks. (2012). Educating students with autism. Retrieved from https://www.autismspeaks. org/sites/default/files/sctk_educating_students_with_autism.pdf

Autism Treatment Centre Ljubljana. (n.d.). Web page of the Autism Treatment Centre Ljubljana.

Retrieved from http://centerza.org/?page_id=554

Baron-Cohen, S. (1997). Mindblindness: An essay on autism and theory of mind. Cambridge, MA: The MIT Press.

Barnard, J., Prior, A., \& Potter, D. (2000). Inclusion and autism: Is it working? London, UK: The national autistic society. Retrieved from http://www.freewebs.com/laset/documents/inclusion\%20 and\%2oautism.pdf

Bogdashina, O. (2005). Communication issues in autism and Asperger syndrome. London, UK:

Jessica Kingsley publishers.

Bryson, S. E. (2005). The autistic mind. In M. L. Bauman \& T. L. Kemper (Eds.), The Neurobiology of autism (2nd ed.) (pp. 34-44). Baltimore, MD: The John Hopkins University Press.

Dobnik-Renko, B. (2009). Autism as a developmental disorder. Retrieved from http://pednevro.pedkl. si/wpcontent/uploads/2008/o7/avtizem.pdf

Dunlap, G., Iovannone, R., \& Kincaid, D. (2008). Essential components for effective autism educational programs. In J. K. Luiselli, D. C. Russo, W. P. Christian, \& S. M. Wilcznski (Eds.), 
Effective practices for children with Autism: Educational and support interventions that work (1st ed.) (pp. 111-137). New York, NY: Oxford University Press.

Društvo za avtizem DAN (n.d.). Web page of Društvo za avtizem DAN. Retrieved from http://www. avtizem.com/

Frith, U. (1989). Autism, explaining the enigma. Oxford, UK: Basil Blackwell.

Grandin, T. (1995). Thinking in pictures. London, UK: Bloomsbury Publishing.

Grandin, T. (2013). The autistic brain. New York, NY: Mariner Books.

Goin-Kochel, R., Mackintosh, V., \& Myers, B. (2009). Parental reports on the efficacy of treatments and therapies for children with autism spectrum disorders. Research in Autism Spectrum Disorders, $3(3), 528-537$.

Hannah, L. (2009). Učenje mlajših otrok z motnjami avtističnega spektra [Learning of young children with autism spectrum disorder]. Maribor: Center Društvo za avtizem.

Happe, F., \& Frith, U. (2006). The weak coherence account: Detail-focused cognitive style in autism spectrum disorders. Journal of Autism and Developmental Disorders, 36(1), 5-25. Retrieved from http://www.ncbi.nlm.nih.gov/pubmed/16450045

Harvey, J. A. (2011). What's so special about special? Improving inclusion for children with autism in mainstream schools (Doctoral dissertation, The University of Birmingham). Retrieved from http:// etheses.bham.ac.uk/3287//

Hill, E. L. (2004). Executive dysfunction in autism. Trends in cognitive sciences, 8(1), 26-32. Retrieved from http://www.ncbi.nlm.nih.gov/pubmed/14697400

Howlin, P., Baron-Cohen, S., \& Hadwin, J. (1999). Teaching children with autism to mind-read. New York, NY: Wiley.

Jones, E. J. H., Webb, S. J., Estes, A., \& Dawson, G. (2013). Rule learning in autism: The role of reward type and social context. Developmental neuropsychology, 38(1), 58-77.

Jurišič, B. D. (2012). Aspergerjev sindrom [Asperger's syndrome]. In A. Klemenc, Kako je biti jaz? Knjiga o fantu $z$ aspergerjevim sindromom (pp. 70-81). Ljubljana: Mladinska knjiga.

Kanner, L. (1943). Autistic disturbances of affective contact. Nervous Child, 2, 217-250.

Kanner, L. (1946). Irrelevant and metaphorical language in early infantile autism. The American Journal of Psychiatry, 151(6), 161-164. Retrieved from http://ajp.psychiatryonline.org/article. aspx? articleid $=143183$

Kenworthy, L., Black, D. O., Harrison, B., Rosa, A., \& Wallace, G. L. (2009). Are executive control functions related to autism symptoms in high-functioning children? Child Neuropsychology, 15(5), 425-440. Retrieved from http://www.ncbi.nlm.nih.gov/pubmed/19173090 Killiany, R. J., Moore, T. L., Rehbein, L., \& M.B. (2005). Memory and executive functions in autism. In M. L. Bauman, \& T.L. Kemper (Eds.), The neurobiology of autism (2nd ed.) (pp. 59-64). Baltimore, MD: The John Hopkins University Press.

Kuhl, P. K., Coffey-Corrina, S., Padden, D., Munson, J., Estes, A., \& Dawson, G. (2013). Brain responses to words in 2-year-olds with autism predict developmental outcomes at age 6. PLoS ONE, 8(5), e64967. Retrieved from https://doi.org/10.1371/journal.pone.0064967 
Lawson, W. (2011). The passionate mind. London, UK: Jessica Kingsley Publishers.

Little, C. (2017). Social inclusion and autism spectrum disorder. In C. Little (Ed.), Supporting social inclusion for students with autism spectrum disorders (pp. 9-20). London, UK: Routledge.

Mayo, J., Chlebowski, C., Fein, D. A., \& Eigsti, I. M. (2013). Age of first words predicts cognitive ability and adaptive skills in children with ASD. Journal of Autism and Developmental Disorders, 43(2), 253-264. Retrieved from http://www.ncbi.nlm.nih.gov/pubmed/22673858

McTighe, S. M., Neal, S. J., Lin, Q., Hughes, A. Z., \& Smith, D. G. (2013). The BTBR mouse model of autism spectrum disorders has learning and attentional impairments and alterations in acetylcholine and kynurenic acid in prefrontal cortex. Plos One, 8(4). Retrieved from https://journals.plos.org/ plosone/article?id=10.1371/journal.pone.0062189

Ministry of Education and Sport. (2011). Law on the placement of children with special needs. Uradni list RS, št. 58/2011.

Mottron, L., Dawson, M., Soulieres, I., Hubert, B., \& Burack, J. (2006). Enhanced perceptual functioning in autism: an update, and eight principles of autistic perception. Journal of autism and developmental disorders, 36(1), 27-43. Retrieved from http://www.ncbi.nlm.nih.gov/pubmed/16453071 Pelphrey, K. A., Shultz, S., Hudac, C. H., \& Vander Wyk, B. C. (2011). Research review: Constraining heterogeneity: The social brain and its development in autism spectrum disorder. Journal of Child Psychology and Psychiatry, 52(6), 631-644.

Richardson, T. (2008). Cognitive and psychoanalytic conceptualizations of autism: A comparative literature review. Undergraduate Research Journal for the Human Sciences, 7. Retrieved from http:// www.kon.org/urc/v7/richardson.html

Schopler, E. (1994). Neurobiologic correlates in the classification and study of autism. In S.H. Broman \& J. Grafman (Eds.), A typical cognitive deficit in developmental disorders - implications for brain function (pp. 87-100). Stockholm: Bokus.

Sicile-Kira, C., \& Sicile-Kira, J. (2012). A full life with autism. New York, NY: Palgrave Macmillan. Tager-Flusberg, H. (2005). Language and communication disorders in autism spectrum disorders.

In M. L. Bauman \& T. L. Kemper (Eds.), The neurobiology of autism (2nd ed.) (pp. 45-58). Baltimore, MD: The John Hopkins University Press.

Turnbull III, H. R., Turnbull, A. P., Wehmeyer M. L., \& Park, J. A. (2003). Quality of life framework for special education outcomes. Remedial and Special Education, 24(2), 67-74.

VanBergeijk, E., Klin, A., \& Volkmar, F. (2008). Supporting more able students on the autism spectrum: College and beyond. Journal of Autism and Developmental Disorders, 38(7), 1359-1370. Warnock, M., (2005). Special educational needs: A new look. London, UK: Bloomsbury Publishing. Wagner, M., Newman, L., Cameto, R., Levine, P., \& Marder, C. (2007). Perceptions and expectations of youth with disabilities. A special topic report of findings from the national longitudinal transition study-2 (NLTS2). New Jersy, NJ: Institute of Education Science. Retrieved from http://www.nlts2.org/ reports/2007_08/nlts2_report_2007_08_complete.pdf

Wei, X., Yu, J. W., Shattuck, P., McCracken, M., \& Blackorby, J. (2013). Science, technology, engineering, and mathematics (STEM) participation among college students with an Autism 
spectrum disorder. Journal of Autism and Developmental Disorders, 43(7), 1539-1546.

Weiss, S. (2010). Posebnosti sociajlnog razvoja dječaka sa Aspergerovim sindromom - studija slučaja [Pecularities of social development of a boy with Asperger's syndrome - A case study]. Napredak, 151(3-4), 482-498.

White, S. J. (2012). The triple I hypothesis: Taking another('s) perspective on executive dysfunction in autism. Journal of Autism and developmental disorders, 43(1), 114-121. Retrieved from http://www. ncbi.nlm.nih.gov/pubmed/22584617

Volkmar, F. R., Reichow, B., \& McPartland, M. C. (Eds.) (2014). Adolescents and adults with autism spectrum disorders. New York, NY: Springer.

Working Group of the Ministry of Health. (2009). Guidelines for integrated treatment of persons with Autism Spectrum disorders. Ljubljana: Ministry of Health.

\section{Biographical note}

Jaka Vadnjal holds a PhD in Business science from University of Ljubljana. He has more than 20 years of teaching and research experience, mostly in the field of entrepreneurship. His favorite research topics are family business and small business finance. However, through practical experience, he also became interested in different pedagogical methods and experience. After many years in academia he returned to industry and serves as CEO of a smaller bank.

Darinka RAdoja is a graduate of Biopsychology at the University of Koper. She continues her studies at the graduate level where her research interests include autism spectrum disorders, their etiology as well as the peculiarities of cognition, due to which individuals with this disorder experience the world around them differently. At her postgraduate studies she is researching biopsychology of autism and related disorders. She is also a mother of a teenager with autism. 